\title{
Framing, Supporting, and Tracking College-For-All Reform: A Local Case of Public Scholarship
}

\author{
Karen Hunter Quartz \\ University of California, Los Angeles \\ quartz@ucla.edu \\ Marco A. Murillo \\ Loyola Marymount University \\ marco.murillo@lmu.edu \\ Beth Trinchero \\ UCLA Community School \\ btrinchero@gmail.com \\ Rebecca Colina Neri \\ University of California, Los Angeles \\ r.neri@ucla.edu \\ Sidronio Jacobo \\ University of California, Los Angeles \\ sidjacobo@g.ucla.edu
}

The college-for-all movement is variously framed as a civil rights issue, an economic imperative, and a requirement for navigating our increasingly globalized society. In response, large urban school districts across the United States have adopted and implemented new policies for graduation that require high school students to complete a college preparatory education. These policies are relatively new, and their implications are just beginning to emerge. As a case of public scholarship, we describe the collective problem-solving process that unfolded over a decade, from 2007 to 2017, as researchers and practitioners in a new K-12 urban public school worked together to expand access to college for traditionally underrepresented students. We describe three practical problems-how to frame, support, and track a college-for-all reform effort-and detail how grappling with these problems locally provides unique insight into the larger college-for-all policy context. In particular, we explore the role of learning supports, status hierarchies, and resources in realizing the college-for-all ideal. We also articulate a fundamental framing tension between social justice as redistribution and recognition and suggest that the notion of parity of participation guide policy and action. 
The college-for-all movement is variously framed as a civil rights issue, an economic imperative, and a requirement for navigating our increasingly globalized society. In response to this idea that all students should earn a college degree, large urban school districts across the United States have adopted and implemented college-for-all policies that require high school students to complete a college preparatory educationoften aligned with the admissions requirements to local state university systems-in order to graduate. These policies are relatively new, and their implications are just beginning to emerge, including drops in graduation rates, a new role for online credit recovery courses, increases in the rates of college enrollment among first generation college students, and shifting relationships between high school, college, and the labor market (Betts, Zau, \& Bachofer, 2016; Domina, Conley, \& Farkas, 2011; Rosenbaum, 2001). These and other policy implications present challenges at the school level that are not yet well documented in the research literature. In this paper, we describe a local case of public scholarship as a collective problem solving process that unfolded over a decade to frame, support, and track a college-for-all new school design.

Part of an in-district reform effort within a large urban district, this new school design was developed as a K-12 school-university partnership school in 2007, just after the district passed a college-for-all policy. The school enrolled its first ninth grade cohort in 2010, offering a college preparatory curriculum to all students and establishing, over time, a strong college-going culture. Our case of local policy implementation belongs to the tradition of what the National Academy of Education (1999) calls "integrated, problem-solving research," a tradition most recently framed as a "research-practice partnership” or RPP (Coburn \& Penuel, 2016). New school designs provide an especially fertile context for RPPs because they are multi-dimensional problem-solving ecologies (Quartz et al., 2017).

In this paper, we situate our case of collective problem-solving in the broad literature on college access, choice, and identity. This rich research base frames how we approach the issue of policy implementation as a research-practice partnership committed to tackling the complexity of the college-for-all problem. We consider student identity and agency, while also attending to the normative and structural dimensions of college-for-all reform. To document the local problem-solving process, we use multiple data sources including surveys, interviews, documents, and student outcome data. Our analysis focuses on three related processes: framing, supporting, and tracking college-for-all. Through these processes, we describe the complexity of taking on college-for-all reform from the perspective of a local school. We conclude with reflections on the strengths and limitations of research-practice partnerships, as well as philosophical and systemic implications for the larger college-for-all debate.

\section{Literature Review}

Capturing the many dimensions and tensions that underlie students' postsecondary transitions is a formidable research challenge. While policies tend to focus on particular levers for change, scholars have documented a much richer landscape. We know, for example, that policies that secure access to college preparatory curriculum focus on only one of many aspects of the college-going process (Conley, 2012). Our study reviews research on school organization and culture, the process of student choice, and the role of cultural assets and identity to illuminate the range and depth of efforts necessary to ensure that all students, particularly, first-generation, low-income students of color, have the academic and social supports to enter and succeed in college. 
How Do School Organizations Promote College-for-All?

Schools play a critical role in supporting students' college enrollment, in particular for students traditionally underrepresented in higher education. Low-income, urban, and immigrant youth are more likely to attend schools that are overcrowded and have limited resources (Balfanz \& Letgers, 2004; Lipman, 2011; Orfield \& Lee, 2006; Valenzuela, 1999). We also know that students who do not have access to effective teachers, rigorous curriculum, magnet programs, and AP and/or dual enrollment courses are less prepared to attend college (Adelman, 2006; Martinez \& Deil-Amen, 2015; Teranishi, 2002). Although these resources are necessary we also know that they are not sufficient to ensure college for all students.

McClafferty, McDonough, and Nuñez (2002) provide a framework for schools to create an organizational culture that promotes college-going and prepares students to make postsecondary decisions. The authors developed the following nine principles to define a college culture: (1) college talk, (2) clear expectations, (3) information and resources, (4) a comprehensive counseling model, (5) testing and curriculum, (6) faculty involvement, (7) family involvement, (8) college partnerships, and (9) articulation. Taken together, these principles provide an integrated approach for creating a school culture in which college-going permeates the school environment. And, while each principle is broad enough to allow schools to implement them according to their particular context, they are grounded in the idea that decisions and actions made must be student-centered and culturally responsive.

Farmer-Hinton's (2011) case study research of a school in Chicago documents the processes taken by educators to address "college for all." The author notes the tensions in designing a college-going curriculum, culture, and rituals that provide academic and social support while also ensuring clear, rigorous expectations across the high school. Research has also identified counselors and teachers as both gatekeepers and inhibitors in the college-going process (Gonzales, Stoner, \& Jovel, 2003; Martinez \& Welton, 2012). While these institutional agents can provide needed information about college, such as college admissions and financial aid procedures, many have overbooked schedules and large student caseloads, which result in difficulty in providing consistent, uniform access for all students to college preparation.

The college preparatory environment must be accessible to all students and help them acquire the knowledge and skills to apply, enter, and graduate from postsecondary institutions (Holcomb-McCoy, 2009, McClafferty et al., 2002). Educators who do not believe in students' ability to succeed in college may be less inclined to provide the information and support students need to enroll in college (Irizarry, 2009; Ochoa, 2013), underscoring the importance of sharing the values, beliefs, and attitudes that every student is capable of entering and succeeding in college. In these contexts, educators are more likely to build caring and trusting relationships with students, provide additional counseling, and scaffold the college choice process (Belasco, 2013; Holland \& Farmer-Hinton, 2009; Knight-Diop, 2010; McKillip, Godfrey, \& Rawls, 2012). Schools where a college-going culture is present show a higher rate of college enrollment (Roederick et al., 2011), and students who feel that teachers and counselors believe in their educational success may have a better transition to college (PerezFelkner, 2015).

To study the school structures that promote college-going, Hill (2008) used latent class modeling to identify and compare college-linking strategies, defined as the processes of planning, applying, and deciding. She placed schools into three categories: 
traditional, clearinghouse, and brokering. Traditional schools offered little support for college enrollment, while clearinghouse schools offered initial planning support, but relied on students' and families to access resources. Brokering schools offered substantial resources and organizational commitment to supporting students. These organizational structures and resources resulted in different college enrollment outcomes, with better results found in brokering schools and mixed results in clearinghouse schools. Engberg and Wolniak (2010) confirmed the importance of collegelinking strategies, specifically the opportunity to develop supportive networks with teachers, counselors, peers, and college representatives. Overall, this rich literature documents the central role that school structures, norms, and expectations play in preparing all students to access college.

\section{The Role of Student Choice}

The college choice literature offers a complementary perspective for understanding how students navigate the college-going process. Traditional models of college readiness and choice have been framed primarily through the experience of White and affluent students (Welton \& Martinez, 2014). For example, Hossler and Gallagher's (1987) three-step college choice model (i.e., predisposition, search, and choice) has been criticized for de-emphasizing the spatial isolation and limited access to school supports that students who are not White or affluent experience (Farmer-Hinton, 2008; Perez \& McDonough, 2008). In contrast, Perna's (2006) extended model, which draws on an economic human capital model as well a sociological concepts such as habitus, social and cultural capital, and organizational context (Bourdieu, 1986) considers multiple dimensions of the college choice process, including four embedded layers: (1) habitus, such as demographics, socioeconomic status, and social capital; (2) the school and community's role in supporting or inhibiting college choice, (3) higher education, such as the role of institutions to recruit students; and (4) social, economy, and policy macro-level factors. These individual and contextual factors offer insight into the many dimensions that shape students' college choices, particularly those who have been traditionally marginalized.

Low-income students, despite possessing the academic qualifications, may choose a less selective college that undermatches their abilities and, therefore, be at higher risk of not completing college (Roderick, Koka, \& Nagaoka, 2011). Researchers also found that despite having the aspirations and qualifications to attend a four-year college many low-income, black, and Latina/o students did not enroll because they never applied (Roderick et al., 2009, 2011). Kanno and Cromley (2015) concluded similar findings for English Language Learner (ELL) students using data from Educational Longitudinal Study 2002. In their study, they found that many ELL students do not participate in the early stages of college planning (e.g., aspiring to college, obtaining the qualifications to apply, and submitting an application). Underrepresented students also tend to be constrained in their college search and college choice (Roderick, Koka, \& Nagaoka, 2011) and obtain information about college from their immediate and extended social networks (Gibson, Gandara, \& Koyama, 2004; McDonough, 1997). These networks often have limited college knowledge about college access because they too have been excluded from the college choice process. As such, students are more likely to be directed towards two-year and less selective four-year colleges because schools do not provide the institutional supports for students to complete the steps to enter college (De La Rosa, Luna, and Tierney, 2006; Kim \& Schneider 2005; Perez \& McDonough, 2008; Person \& Rosenbaum 2006). 
Building on Students' Assets and Cultural Identities

Traditional models of college readiness, while examining social inequities, tend to focus on supposed deficits and challenges facing underrepresented students: lower aspirations, lack of family experience with higher education, negative or limited peer support, insufficient financial resources, neighborhood dynamics, and lack of mentors (Pike \& Kuh 2005; Tornatzky, Cutler \& Lee, 2002; Zirkel, 2004; Noguera, 2003; Stanton-Salazar, 2001). Instead of focusing on deficits, researchers argue that college readiness models should build upon the social and cultural resources, or funds of knowledge, of underrepresented students (Delgado Bernal, 2002; Rios-Aguilar \& Kiyama, 2011), including family- and community-level assets and extended social networks (Ceja, 2006; González, Stoner, \& Jovel, 2003; Perez \& McDonough, 2008). Many argue that meeting students' college-going needs must extend beyond addressing what underrepresented students and their families lack.

Yosso (2005), for example, offers a theory of community cultural wealth that describes six different types of capital that students of color often bring to the college-going process, including aspirations, bilingualism, and familial capital. Using the community cultural wealth framework, Liou, Antrop-González and Cooper (2009) studied the information networks and college-going identity of Latina/o students at two urban, racially segregated high schools. Their study "dispels the normative notions of Latina/o pathologies in school failure but also illuminates that students' communities are rich and dynamic in supporting students' college-going aspirations.” (p. 552) Similarly, Oropeza, Varghese and Kanno (2010) studied four linguistic minority female students' retention and persistence in college, demonstrating how they used their community cultural wealth to access and navigate college. As this research indicates, studies of college-for-all reforms must capture the complexity and richness of the knowledge, skills, and relationships that low-income students of color bring to the college-going process.

\section{Approaching the Complex Problem of College-for-All}

Our study seeks to shed light on how schools frame, support, and track college-forall reform initiatives, particularly for students underrepresented in college. To do this, we approach this complex problem from different levels and perspectives, and building on the research reviewed above. We consider the role that student identity, agency, background, and culture plays in preparing students to aspire to, apply to, and enroll in college. Our study also attends to the organizational supports schools need to develop in order to serve all students. These supports are varied and extend beyond the counseling office to include resources to prepare all students for college. We recognize that these supports are in turn shaped by the values and beliefs held by the educators who work in schools, and therefore we attend to the normative as well as structural dimensions of college-for-all reforms. Our study is situated in a particular political context, a large urban district college-for-all policy mandate. From the perspective of a district reform, our study tracks how this mandate plays out on the ground. And finally, our study extends beyond high school to investigate the equity concern that college-for-all may be further stratifying our systems of higher education. This multi-level and multi-dimensional approach reflects the problem-solving orientation of our public scholarship as well as research on school reform more generally (e.g., Oakes, Quartz, Ryan \& Lipton, 2000). 


\section{Methods and Context}

\section{Integrated Problem-Solving Research}

The National Academy of Education (1999) offers a helpful definition to frame integrated problem-solving research. First, problem-solving research and development should be committed to the improvement of complex systems, not solving narrow issues. Second, researchers and practitioners should identify the features of the problem space together and co-construct tools and approaches to solve the problem based on their own expertise and authority. Third, problem solving should involve long-term engagement, stable professional relationships, and continual refinement. And finally, the collaborative study should result in principled explanation about how and why things do or do not work. This definition captures our study's intent and methods well. This type of research has been called use-inspired basic research based on the assumption that "much useful knowledge about education practice must be jointly constructed by researchers and practitioners"' (NAE 1999, p. 30). More recently, this type of inquiry has been called a research-practice partnership (RPP).

RPPs operate differently from traditional models of collaboration between researchers and practitioners as they are mutualistic, long-term relationships that use intentional strategies to address problems that are relevant to practice (Penuel, Allen, Coburn, \& Farrell, 2015). In RPPs, researchers and practitioners are committed to developing mutually agreed upon and explicit goals and addressing them through sustained, longterm collaboration over multiple projects (Coburn, Penuel, and Geil, 2013). Not only can the findings from these partnerships validate scholarly research, they provide deeper insight into the relationship between implementation, outcomes, and context and productively nuance ideas of generalizability and scale-up (Gutierrez \& Penuel, 2014). In this way, RPPs or integrated problem-solving research methods conceive of human agency as collective problem-solving within particular social structures and in response to particular social policies. As Coburn (2016) reminds us "the question of policy implementation is fundamentally about the relationship between social structure and agency" (p. 466). Our study attends to the structure-agency relationship by unpacking the school-based processes of collective problem-solving in response to a college-for-all policy reform.

While RPPs hold great promise for addressing complex educational problems, such as designing and implementing a college-going culture for all students, RPPs do not come without their challenges. On an interpersonal level, RPPs must build and maintain trust between researchers and practitioners while also navigating inequitable power dynamics (Penuel et al., 2015). On an organizational level, the alignment between the goals, communication and collaboration styles, and timelines of researchers and practitioners can be challenged by opposing incentive structures, lack of capacity and expertise, and funding structures (Coburn, Bae, \& Turner, 2008; Sirotnik \& Goodlad, 1998). On a national and local policy level, RPPs face issues of generalizability and scale-up as they are often single-site projects and, through designing with practitioners and districts, lose objectivity (Anderson \& Shattuck, 2012; Kelly, 2004).

Our study examines the processes and outcomes of a research-practice partnership aimed at designing and implementing a college-going culture in a K-12 schooluniversity partnership school. In addition to student outcomes, we describe moments of organizational change and the challenges of designing and implementing a successful RPP. In order to develop principled explanations about how and why the school's efforts to prepare all students for college worked or did not work, we rely on multiple data sources. These include: annual student and teacher surveys; college 
application, admissions, commitment, enrollment, and persistence data; school meeting and planning notes; annual accountability reports; and a set of 10 interviews conducted in 2016 with students who graduated between 2012 and 2015 to capture the different postsecondary experiences of alumni. These data were systematically collected, analyzed and used by teams of researchers and educators working together within a variety of structures. These structures included the school's leadership team, the university's partnership team, the shared governing council, annual partnership retreats, and monthly meetings of the research and accountability committee. We present these data below according to the three main problems that defined our RPP: how to frame, support, and track college-going of traditionally underrepresented students. Our collective problem solving was shaped by two overlapping contexts: new school design as well as the implementation of college-for-all policy in a large urban school district.

Context: New school design. Our study was conducted at the UCLA Community School, one of the more than 8,000 new schools that have been created this century in an effort to broaden educational opportunity (National Center for Education Statistics, 2016). Alongside new policies that spur the development of new schools (e.g., charter school laws and local autonomy initiatives), there is a growing movement in higher education to promote civic responsibility by creating a new generation of universityassisted K-12 schools (Benson, et al., 2017). These public schools are designed to prepare low-income students of color to flourish in college, thereby disrupting persistent patterns of inequity. These new schools are also poised to take on our field's longstanding struggle to integrate research and practice (National Research Council, 2012) by providing a fertile context for research-practice partnerships (RPPs). Our study is situated within this broad and growing new school design context (Cucchiara, 2010; Quartz et al., 2017).

The Lower School opened in the fall of 2009 with 340 K-5 students. An additional 500 students in grades 6 through 11 enrolled the next fall, and by 2011 the school was fully enrolled with approximately 1,000 K-12 students. The school's rapid expansion from Kindergarten to 12th grade in 3 years-rare in new school development-was necessary given the overcrowded conditions and need to bus students out of the neighborhood. Attending to the start-up challenge of creating a cohesive and supportive school culture for students with diverse prior school experiences left few opportunities for researchers and practitioners to collaborate in the school's first three years. RPP activities during the early years were focused on student assessment and the need to establish data systems. Recognizing the need to focus intentionally on the school's college-going culture, the school held a full day partnership retreat in June 2013 to take stock of the work to date, review research, and articulate a stronger set of supports for college-going. This paper therefore focuses on the RPP activities from 2013 to 2017 to frame, support, and track college-for-all.

College-for-all policy context. On June 14, 2005, the Los Angeles Unified School District approved the "A-G For All Resolution," establishing a fifteen-course college preparatory sequence for all students beginning in 2012 with the incoming class of 9th graders. The A-G requirements are a set of courses that students must pass with a $\mathrm{C}$ or higher to be eligible to apply to University of California and California State University (UC/CSU) institutions (University of California, 2017). For reasons that have been well documented through research on urban schools-quality of teaching, lack of resources, large class sizes, effects of poverty, school culture-students of color and low-income students face difficulties in meeting A-G requirements and therefore, experience less 
access to UC/CSU institutions (Darling-Hammond, 2000; Gandara \& Contreras, 2009; Howard \& Milner, 2014; Ladson-Billings, 2006; Noguera, 2009). To combat these inequities, coalitions of community-based organizations in cities across California organized campaigns to demand that all students receive college preparatory coursework. Resulting from these efforts, major urban districts across California adopted graduation policies that require all students to complete A-G courses in hopes of putting more students on track to attend a public university. The A-G For All Resolution is part of this larger state reform context and the UCLA Community School was established in the context of its scale up and implementation. A decade of implementation challenges and threats to the graduation rate shaped a change to the policy in June 2015, when the Los Angeles Unified School District Board of Education formally recommitted to "A-G For All." In place of the UC/CSU "C or higher" admissions requirement for the A-G courses, the Los Angeles Unified School District lowered the standard to a "D or higher" for high school graduation in 2016.

\section{Analysis}

\section{Framing Problem: Justice as Redistribution or Recognition?}

Ensuring that all students graduate high school college-ready involves identifying and solving a myriad of practical problems, including providing access to appropriate, high-quality curriculum and instruction; setting up learning support systems for struggling students; ensuring students and their guardians have access to information about the college-going process; and so on. Yet, there is also a core philosophical tension that has framed much discussion and deliberation at our school. In June 2013, when a group of 20 researchers and practitioners convened as a collaborative working group to assess and improve the school's college-going culture, this tension surfaced. One of the university partners stated that " 100 percent of students attending this school must go to college." He explained that this was the goal at more affluent schools and that this worthwhile goal should be the goal of this RPP. The statement caused a commotion, especially among some staff members who questioned whether the idea of college-for-all was philosophically aligned with the social justice vision of the school.

The school's vision (outlined in its 2007 new school proposal) is to advance social justice through education. Interpreted as a broad commitment to disrupting economic, political, and social inequality through education, this original, frame-setting vision focuses on distributive justice and the importance of brokering access to college as a way to redistribute a social good that has been traditionally denied to low-income students of color. Yet, this framing of social justice education as collective solidarity for redistribution sits alongside another conception of social justice as recognition, rooted in the cultural politics of difference and respect for persons as free and equal human beings. On this view, advancing justice involves embracing cultural identity and difference--and the drive for self-realization--in contrast to universalizing dominant group norms such as college-for-all. Framed as a practical problem, the question is: How does a school both press all students to attend college while also recognizing the agency and identity of individuals, particularly those young people who express no interest in attending college?

Consider the case of Juan (a pseudonym), Class of 2014, who was interviewed in 2016 about his high school experience and postsecondary pathway. In 9th and 10th grades, Juan failed most of his classes. In his senior year, Juan's advisor motivated him to retake many of his classes online and he ended up graduating on time. Asked how she did this, Juan replied: “Just, I don’t know, sometimes you need someone to talk to you, you feel me? And tell you things straight up. And she wasn't afraid of telling me things 
straight up. It was like, you're right." Others offered similar support that Juan credits for turning him around. Despite graduating on time with a 2.3 GPA, with advisors and counselors providing resources and encouragement, Juan did not apply to college. Asked why, he responded: "Cause I didn't want to go to college. I would just be like, nah. And then I fell back on the deadlines, so like, that was all on me. I didn't know what I wanted to do." After missing the four-year college application deadlines, the principal, counselors and teachers urged Juan to attend community college. In what he describes as a "personal decision," Juan opted to take a year off and work nights as a security guard. He had seen his sister attend community college for the past five years without earning her Associate's degree. Juan's mother helped him make the decision to wait a year and apply to a local four-year public university because she didn't want him to fall into the same trap. The next year, Juan returned to the school for support in applying to college, was accepted to several four-year institutions, and opted to attend one near his home while continuing to work. Looking back on his decisions in senior year, Juan expresses regret and explains that he "was being a little rebel."

We share this case to highlight the school's role in preparing Juan to be a free adult who constructs his own identity-recognizing that it glosses over the many systemic issues at play. Could the school have done more to avert Juan's college application rebellion in senior year? Or, was this rebellion part of Juan's developmental trajectory to gain insight into his own interests and identity? The tension heightens when we consider other cases that do not result in eventual college enrollment. It may be reasonable to accept Juan's year off as a formative stage in his college-going pathway, but what about other students who choose not to attend college? What about students whose economic and social circumstances make working after high school more valuable to them than attending college? To address this practical problem, our research-practice partnership has had to grapple with fundamental beliefs and values about the role of schools in the lives of young people.

Articulating and addressing different conceptions of social justice has been central to the school's development of its college-going culture. The debate has played out in the lunchroom, in faculty meetings, in debates about grading policies, and during budget discussions about allocating resources to college counseling. Through these debates, the school is grappling with how to both distribute college-going resources and opportunities while also recognizing and respecting students as self-directed passionate learners. We turn now to the ways in which practitioners and researchers developed school structures and programs to support a college-for-all culture that also values student agency and freedom.

\section{Supporting College-For-All and Identity Development}

The June 2013 partnership retreat kicked off with a review of research on the components of a college-going culture, including counseling, access to information, rituals and traditions, and social networks. The group reviewed a report of three years (201113) of student survey data related to college-going, including students' college knowledge, experiences, and future plans. These data revealed many areas for improvement and the need to develop more formal systems of support. By the end of the day, the group had agreed on a set of K-12 supports, described below. We document the challenges we faced as a partnership and specific actions we took to move the work forward.

Professional college counseling and center. When the school opened in 2010, a parttime volunteer college counselor supported students in a small office wedged between 
the main office and a workroom. Often dubbed the "college closet," the space was cozy, but ineffective when needing to serve large numbers of students. The school decision to both hire a professional college counselor and move the college center to a larger, more functional space met with some initial resistance. The School Governing Council, comprised of university partners, K-12 teachers, school leaders, parents, and students, makes budget decisions. Allocating funds to a college counselor was a contentious decision because the elementary faculty were advocating for resources to reduce their class size and did not see college counseling as benefiting students in the early grades. After much discussion, the college counseling position was approved, and a job description was created, including the following statement about the school's values:

As a social justice school, we work towards 1) giving access and equity to all students, and 2) creating a new narrative for minority students that takes into account the richness of their experiences. We expect ALL our students to be prepared for college and career.

The college counselor navigates the need to respect students' identities and to uphold the RPP's goal of increasing college access for all students. Additional challenges include building a college-going culture that is developmentally appropriate and accessible to all students in grades K-12. In many ways, the college counselor serves as an intermediary in the RPP; she is a core member of the research and accountability committee and works closely with university partners and school staff in order to bring about praxis at the school site. For example, to advance expectations for college-going in the elementary grades, the counselor mentored a UCLA undergraduate intern to study and develop ways to engage younger children in thinking about college.

Developing strategic alliances. A core responsibility of the college counselor is coordinating and integrating a myriad of programs and college-going resources so they reach and support all students and their families. This is no small feat and requires deft judgment calls, strategic alliances, and constant brokering. For example, the school is co-located with five other schools, all part of a large campus serving 4,000 students. A regional GEAR-UP program, a federally funded college access program for first generation students, serves students across the schools, providing college workshops, SAT prep, peer mentors, counseling, and field trips for select cohorts of middle school students. Similarly, the partner university's Early Outreach Academic Program provides a site coordinator and student worker who offer direct services to support a select cohort of four-year bound students in grades 10 and 11. The program also offers oncampus college access workshops, overnight visits to the college, and skills-based workshops to support first generation students. In 2015, the school also contracted with a college access program, which provided parent and student workshops around college-going, choosing a major, networking, and A-G course selection. This program served 15 families in the high school, but proved to be too expensive to continue in subsequent years. As these three examples demonstrate, there are varied external support structures provided to schools. Each serve particular groups and come with costs and/or requirements that fall on school personnel to manage.

The school has discussed the value of tracking student participation in different programs in order to ensure an equitable distribution of resources. For example, many programs offer college visits to students, and the school also organizes a variety of field trips to college campuses. At the June 2013 retreat, the team recommended that the school track the number of visits each student makes to a college campus in order to ensure that they visit at least four campuses, including two-year and four-year, as well 
as private and public institutions, over the course of their high school years. The annual student survey data collection attempted to track campus visits, but the research committee felt strongly that the survey should be anonymous because it included sensitive and evaluative information about the school. Alternative strategies for collecting systematic data by program (e.g., campus visits, SAT prep courses, financial aid workshops) and student have proved too demanding. Instead, the college counselor and others have had to rely on informal tracking, school communication systems, and their relationships with students to distribute opportunities.

In addition to strategically allying with college-access programs, alliances have been developed within the school to support college going. Advisory teachers, for example, help students explore colleges and share their own college-going stories with students. Through its curriculum, the English department supports students to craft their personal essays and statements for college applications. Over time, the school's senior internship program has developed to be intentionally mindful of helping students prepare to apply to college as well as develop their college going identity. As a longstanding RPP at the school, the internship program illustrates the process of creating, studying, and improving learning opportunities that help advance college-for-all.

Initially created as a pilot elective course that enrolled eight students in its first year, the internship program evolved into a required course for 70-80 seniors each year. Two teachers serve as the internship coordinators and prepare students to engage in and reflect upon their work-based learning experience as part of a core Applied Economics course. The educators are intentional about providing work-based learning opportunities that build on students' personal knowledge, experiences, and passions. Between 2011 and 2015, 229 students chose to intern at one of 75 different internship sites, including non-profit and advocacy organizations, governmental agencies, university departments, and private sector businesses. Throughout the internship experience, students are mentored by site supervisors who facilitate a formative experience of college and career preparation. The expanded networks students develop through the internship program are also designed to honor and build upon their community cultural wealth. Through these experiences and networks, students begin to see themselves as transitioning from high school into the world of college and career. In this way, the program supports both college access and identity formation.

A variety of data, including surveys, observations, and interviews, on students' internship experiences have been collected since 2011 and continue as part of an annual cycle of program improvement. These data have helped define several of the program's key elements. For example, in 2013, data showed that that seniors who interned in the fall semester were using the internship experience in college essays and applications. Therefore, the school decided to not offer the program in the spring and change the course matrix to enable all seniors to enroll in the fall. Through the data collection efforts, the school also learned that $38 \%$ of the interns reported using Spanish at their internship site, $3 \%$ spoke Korean, and $2 \%$ spoke another language. These data affirmed and helped inform the school's commitment to biliteracy and also helped foreground students' linguistic capital as valuable to their college-going identity.

College-going rituals and celebrations. Through the creation and use of college going rituals and celebrations, the school communicates that college is for all students. In 2014, the school created an event called the College Kickoff, held during the first week of October to officially open the college application session for seniors. One tension in this season is the different application deadlines and timelines for two-year versus 
four-year colleges. To be as inclusive as possible, the college counselor invites a community college representative to attend. With food, decorations, and music, the event has become a fun, festive way to encourage all seniors to participate in the college-going process. Attendance each year has grown, and in 2016, $80 \%$ of the senior class participated.

Other rituals include a Senior Parent Orientation meeting at the start of each school year and a Spring Senior Parent meeting to discuss financial aid, college acceptance process, and matriculation to college. For students in grades 6-12, annual Advisory sports tournaments, in soccer and basketball, have been revamped to incorporate college teams and information about different colleges. These tournaments are popular among students and raise awareness of different types of colleges, including public and private schools in the state and nation. And finally, to engage elementary students, the college counselor initiated an annual K-5 college-going parade in 2015 to symbolize that students are on a college track. The event is accompanied by short lessons around college-going that teachers can complete in their classrooms.

The festive and inclusive intent of these college-going rituals stands in contrast to moments when students experienced the status hierarchies that define postsecondary pathways. Early in the school's development, students reported feeling "less than" or ashamed if they were either not qualified to or chose not to attend a four-year college. At a poignant school assembly in 2014, seniors were required to stand up and say where they were going to college in front of their peers. Many community college bound students resisted or didn't participate. Students became identified by teachers and counselors according to their qualifications (e.g., the "UC kids"). Spring celebrations of the students who were admitted to selective colleges were lauded by the university partners, affirming the value of selective four-year colleges over less selective ones and community colleges. All of these actions signaled to students that while college may be for all, there was a definite pecking order. This concern was taken up at a partnership retreat in 2017 and the group agreed to make a concerted effort to affirm the value of all postsecondary pathways.

\section{Tracking Problems: Measuring College-for-All}

Running alongside the effort to develop and implement a college-going culture, our RPP grappled with how to measure college readiness, capture college-going, and track the transition to and through college. A Research and Accountability Committee (RAC) comprised of school administrators, teachers, and UCLA researchers established protocols for collecting and analyzing college-related data. In doing so, the committee had to solve several problems, make many judgment calls, and figure out the best ways to share the data to inform the school's practice. We share this problem-solving process below, according to three types of data: college readiness, college intentions, and postsecondary pathways.

College readiness. Students' progress toward college was measured using multiple sources at different time points. The school used district data systems to track the number of credits each student earned at the end of each high school year to determine who was "on track" for graduation. With the "A-G For All" policy in place, these credit data were also associated with the courses students took and whether they met the " $C$ " or above grade threshold required for admission to the state's public universities. As described above, completion of the A-G requirements indicates that a student has acquired broad and in-depth knowledge in multiple academic subjects; the "A" requirement, for example, includes one year of world history and one year of US history. 
These credit, course, and grade data are used by the district to provide early warning systems for schools, to enable them to identify students not on track and provide remediation. The district also collects annual student survey data to track how many students know about the A-G requirements and whether they are on track to meet these requirements. For example, in 2014-15, these district data revealed that only $48 \%$ of students were on track to complete A-G requirements with a "C or better," $83 \%$ of students reported knowing what A-G courses they need to take to get into college, and $78 \%$ knew their current status toward meeting the requirement.

To supplement the district data, the RAC decided to administer its own survey each spring to students in grades 7-12. The survey includes items about college and career preparation, students' knowledge about college entrance requirements, educational goals, and concerns about attending a college of their choice. In addition, $12^{\text {th }}$ grade students are asked about their experience during the college application process, postsecondary plans, and what they considered when deciding the colleges they plan to attend in the fall. These data are used to make informed decisions about how to support students in the college-going process. For example, data from the school's first graduating class in 2012 showed that $41 \%$ of senior students did not complete a Free Application for Federal Student Aid (FAFSA). The high incompletion rate is partially explained because the school enrolls a high number of undocumented students and at the time they were ineligible to receive any form of financial aid. Still, in the following years increased attention was given to ensuring students completed financial aid applications. The school hosted information sessions for students and parents and encouraged parents to sign-up for one-on-one support with the college center. Students were also called to the college center and were walked through the application by the college counselor or a volunteer. By 2016, every graduating senior submitted a FAFSA or a California Dream Act application.

Capturing college plans. Measuring progress to college also brought to light the importance of capturing students' college-going plans. One of the first issues the RAC grappled with was who to include in the data collection and reporting. Initially, the group decided to include all seniors who were enrolled on April 15th, based on the rationale that this would provide the most accurate representation of college-going rates. In 2015, however, the school changed course to enable national and state comparisons, conforming to the more commonly reported college-going rate of high school graduates (e.g., Felkner-Perez, 2015, p. 20; Mehan, 2012, p. 28). It is important to note, however, that the school also measures its progress in preparing all students for college using the four-year cohort graduation rate as well as the percentage of graduating seniors who plan to enroll in college. Initially, members of the RAC tried to count and track down all students in the school's first 9th grade cohort in order to calculate college-going in relation to the four-year cohort graduation rate in 2014. When the committee's graduation rate conflicted with district's reported rate, the RAC consulted with the district and learned that it was virtually impossible for a school to reproduce the district's data. It is also notable that the state calculates the four-year cohort graduation rate using a different method, resulting in a different rate. From the perspective of the school, these high-stakes calculations are eagerly anticipated yet far removed from the daily tracking routines of the research committee and administrative offices. For this reason, the school decided to calculate its college-going rate relative to the number of seniors in the graduating class.

Confirming students' college plans proved more difficult than initially expected. In the first year (2012), the school relied on student self-reporting through an online survey. 
However, descriptive analysis indicated students' misreported college acceptance and commitment. The following year, a UCLA student volunteer conducted one-on-one interviews with seniors to ascertain students' college plans and financial aid. Although this method yielded more accurate results, it was time consuming for the school and concerns arose about students sharing personal information with an individual they did not know. For this reason, the decision was made to use multiple sources at different stages of the college-going process to determine students' college plans. By 2013-14, the college counselor and university researchers collected college-going data at multiple stages, including the college applications students submitted in the fall/winter, the admission outcomes that followed in the spring, and students' intention to enroll on May 1st, National College Decision Day.

The application data enabled the RPP to understand the number and types of college applications submitted. These data revealed that very few students were applying to private or out-of-state colleges, which prompted an effort the following year to encourage a broader set of applications. The admissions data allowed the school to report how many students were accepted to the partner university and broader state system of higher education--both important accountability measures for the school. The intention to enroll data, however, proved more difficult to track and report. After rushing to collect the information from students the RPP team realized that setting a May $1^{\text {st }}$ deadline constrained the accuracy of college-going reporting. First, a few students who were still undecided submitted more than one Statement of Intent to Register (SIR). Second, some students were still waiting to hear about their financial aid packages. And third, many students who planned to attend a two-year college were still undecided about where to commit. Given these implications, by the 2015-16 school year, the decision was made to capture college-going plans up until graduation day in midJune. By then, all students had a postsecondary plan and the school used these plans to calculate a "college-going rate" that distinguishes between plans to attend two versus four-year colleges.

Figure 1 summarizes seniors' postsecondary plans for the classes of 2014, 2015, 2016 and 2017. Year-to-year results show that while students' plans to attend a college/university remains relatively the same, there has been growth in the percentage of seniors planning to attend a four-year college/university (59\% in 2014 to $68 \%$ in 2017). We attribute this increase to the school's targeted efforts to increase the A-G readiness rate as well as encourage more students to apply to and attend four-year colleges. Further study is needed, however, to substantiate this claim.

College enrollment and persistence. Given the school's commitment to prepare all students to enter and succeed in college, the RPP team initiated a major effort in 2015 to track the college enrollment and persistence of UCLA Community School alumni. At the time, tracking college enrollment was mostly limited to anecdotes from students who visited the campus. The team created survey as well as qualitative interview questions about students' postsecondary paths and how their experience at UCLA Community School prepared them to transition into college. To track college enrollment, the team purchased a license with the National Student Clearinghouse (NSC) to provide aggregate and detailed information about graduates' enrollment patterns. Three times per year, the NSC delivers a report that includes information about each alumni class' immediate college enrollment after high school graduation, anytime enrollment during the first year, persistence, retention, overall enrollment, and graduation. The reports also include demographic information such as enrollment by gender and race/ethnicity. 
Figure 1: UCLA Community School Students’ Postsecondary Plans

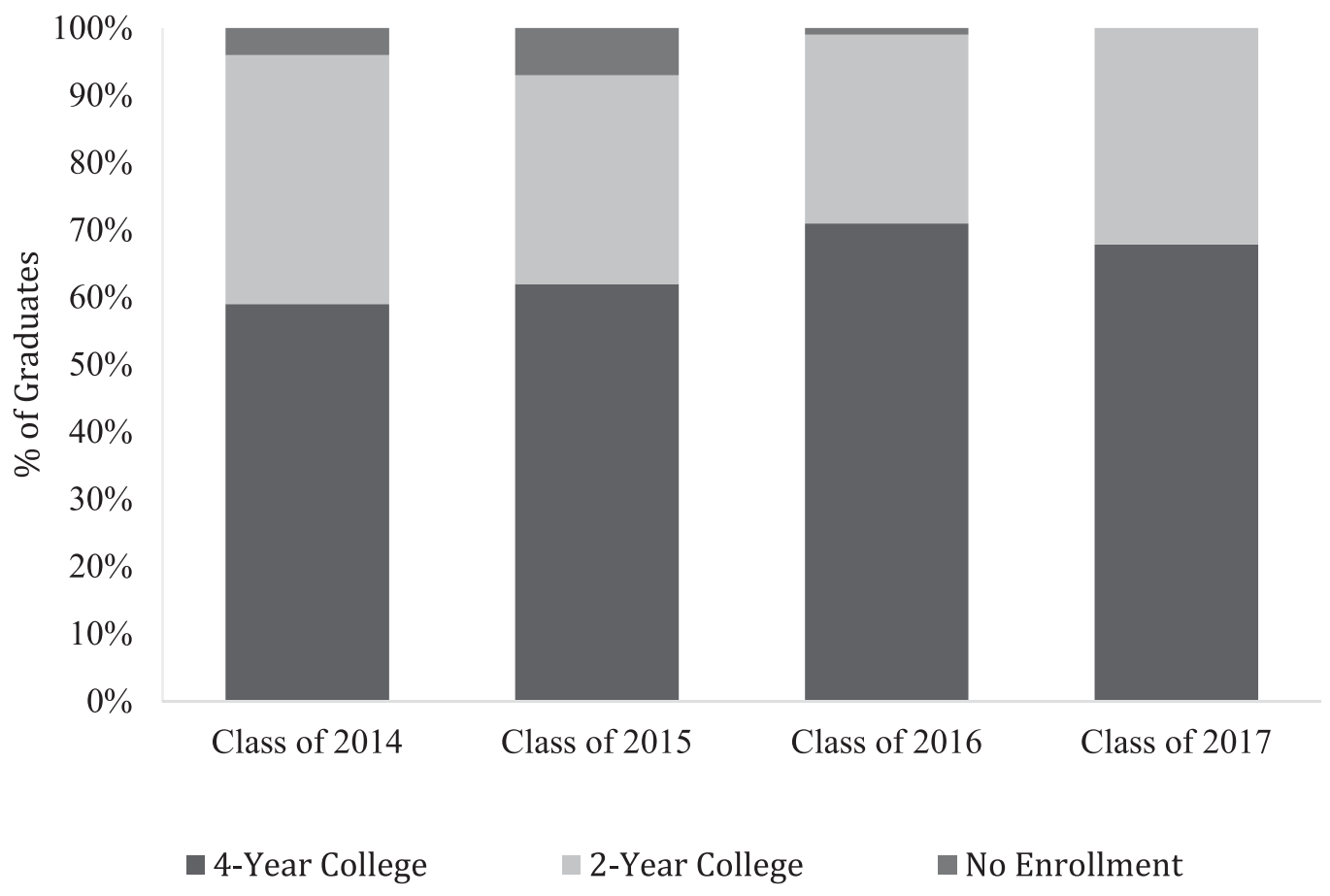

The RPP team learned that the student-level information submitted to the NSC does not always result in a student match. One group whose college enrollment may be particularly underreported is undocumented students who are more difficult to track because they may lack a Social Security number. In addition, the NSC provides a detailed report of student-level enrollment. The detailed report includes information about the institution where a student enrolled, the semester/quarter they were enrolled, their enrollment status, and if they completed a degree. However, unlike the aggregate reports which include information on every student that was found, the detailed report omits the information of certain students. One reason may be that a student may have opted-out from allowing their institution to share identifiable information about their enrollment status. To complete the missing data of the detailed report and to report college enrollment more accurately, UCLA Community School took multiple steps to track college enrollment.

A Postsecondary Education Enrollment database was created to track the postsecondary paths of UCLA Community School alumni during the first two years after graduating from high school as well as information about degree completion. The database was first populated using detailed information from the NSC. Although the database includes information for every alumni class, due to capacity issues, the RPP decided to complete enrollment data (i.e., missing data) beginning with the class of 2014 , the school's first $9^{\text {th }}$ grade cohort. Second, the RPP took multiple approaches to data collection, such as survey administration, checking in at Homecoming events, and individual follow-ups conducted with teachers, counselors, and other staff personnel. This process helped yield immediate college enrollment data for $93 \%$ of the Class $2014,97 \%$ of the Class of 2015, 89\% of the Class of 2016, and $90 \%$ of the Class of 2017 . 
Figure 2: Comparison of Immediate College Enrollment Between UCLA Community School Students and NSC Sample

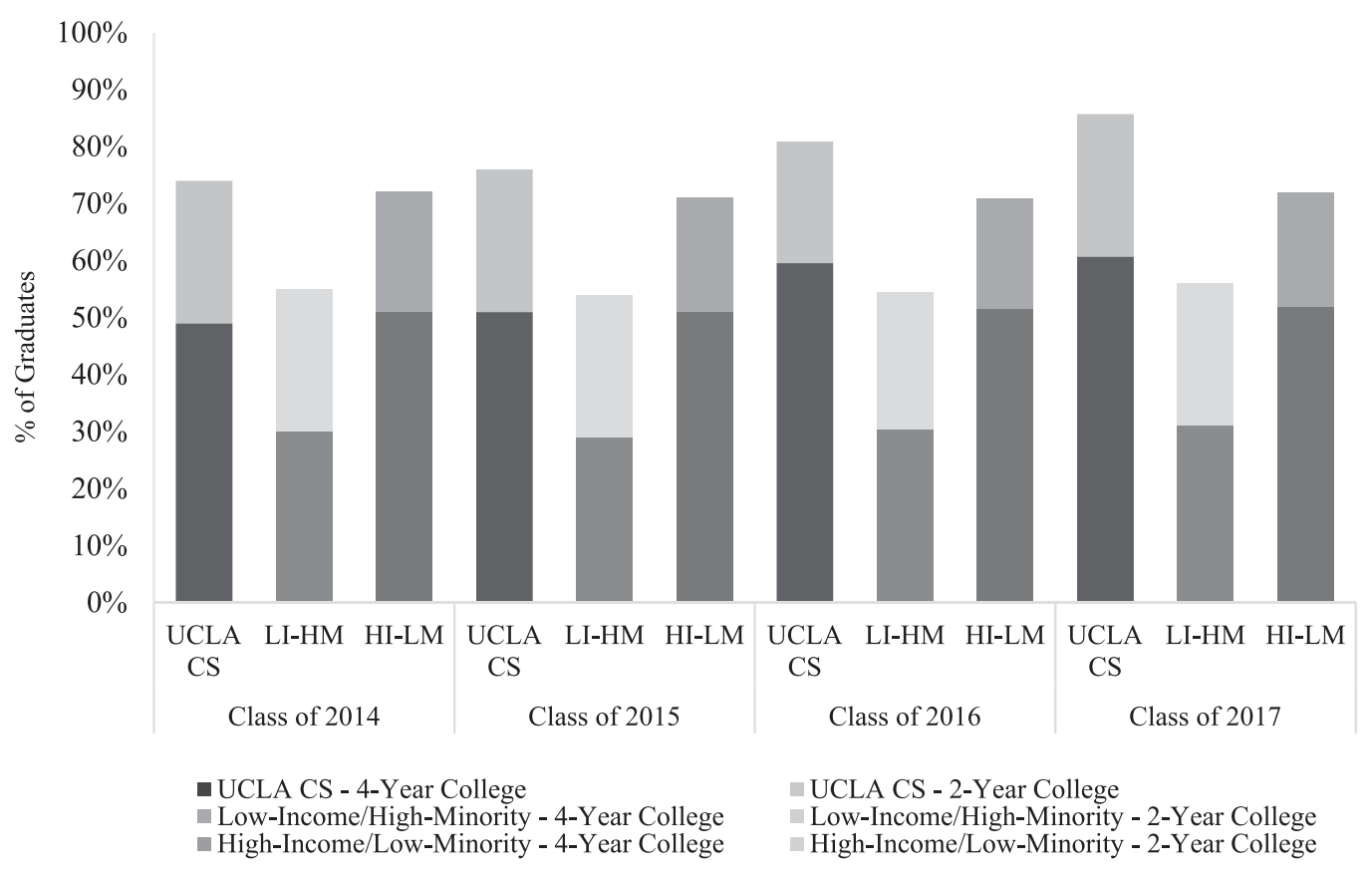

Utilizing multiple sources to determine college enrollment also provided an opportunity to compare the school to others across the nation. For example, Figure $2 \mathrm{com}$ pares UCLA Community School students' immediate college enrollment during the fall after high school graduation with a comparison sample provided by the NSC. It is important to note that the NSC data is not comprised of a nationally representative sample. Still, it provides a snapshot of how our students are faring in comparison to students who attended similar high schools. For example, the Class of 2017 had a higher rate of immediate college enrollment (86\%) in comparison to low-income, high minority schools (56\%) as well as high-income, low minority schools $(72 \%)$.

In addition, the school is committed to following the postsecondary trajectories of students through college. Figure 3 examines college persistence based on students who were enrolled in the first year after graduating from high school and returned in the fall of the second year using the NSC comparisons. Results show UCLA Community School students persist at higher rates than college students in California and across the nation. (For more information, see Jacobo and Quartz, 2019).

Complicating these NSC comparisons, we learned through our qualitative interviews with alumni that their pathways through college may not be captured by static enrollment and persistence data. For example, one student started community college after high school but then took a leave to have a child and later re-enrolled. Across the Class of 2014, we found a diversity of pathways in and out of two and four-year colleges. These trajectories provide insight into the different needs and circumstances students encounter after leaving high school and the limitations of enrollment and persistence rates in capturing students' postsecondary success. 
Figure 3: College Persistence: Comparison of NSC National and State Trends

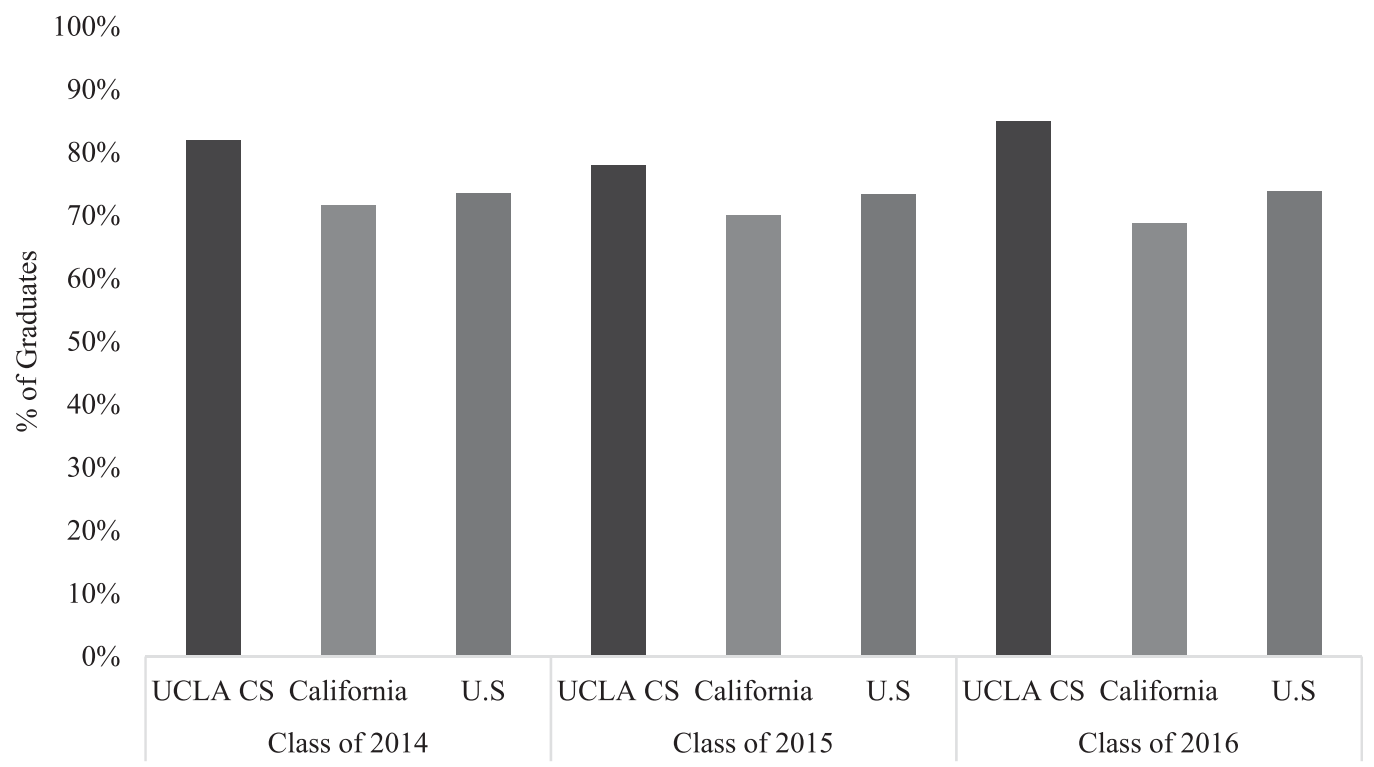

\section{Discussion \& Implications}

This paper has documented the collective problem-solving process of a group of researchers and practitioners working to expand access to college for traditionally underrepresented students in a K-12 urban public school. We describe how we addressed and attempted to solve three practical problems--how to frame, support, and track a college-for-all reform effort. As a case of public scholarship, this research-practice partnership has informed local practice and program development as well as enabled the school to be accountable to its many stakeholders (students, parents, district, university, community) by supporting and tracking college-going--students' college plans, enrollment, and persistence. Several themes well documented in the RPP literature surfaced throughout this case, strengthening our understanding of how RPPs can productively marry research and practice in education. Following a discussion of the nature of RPPs, we turn to the broader implications of our collective problem solving to inform the current college-for-all policy context and research literature.

\section{The Value and Challenges of RPPs}

Infrastructuring: A foundation for change. Documenting the process of framing, supporting and tracking a college-for-all reform helps capture the school-level infrastructure-the tools, relationships, definitions, and protocols-teachers, counselors, and administrators rely on to do their work. Building this infrastructure, infrastructuring, is a dynamic and continual process that also defines the work of a research-practice partnership. Collaboratively designing tools such as the school's college-going databases, for example, provide common metrics for gauging improvement and growth. Annual survey protocols like the college center's focus on FAFSA preparation are another tool that can help RPP teams reflect on practice and set priorities. District and state data systems and infrastructure sit alongside these schoolbased data collection efforts, providing complementary sources of information such as the A-G readiness data and early warning systems (Phillips et al., 2015). As we found in the case of the four-year cohort graduation rate, however, it can be challenging for schools to access, replicate, and use these data. 
Setting up and maintaining data systems are not the only form of infrastructuring. The RPP also helped establish rituals, structures, courses, expectations, and school-wide norms for college-going. For example, the internship program was co-designed to promote college-going; the college kick-off brought people together to support the application process; the school-governing council decided to hire a full-time college counselor; and the college center moved to a prominent location between the lower and upper schools to increase visibility and use. These structures were developed by researchers and practitioners working together, based on systematic inquiry and democratic processes.

The framing problem addressed by the RPP also added to the school's infrastructure. As Penuel (2015) describes, "infrastructuring focuses on building a foundation for change, attending to who and what is already there, while seeking to build networks that can take on the difficult work of making significant and broad changes to educational practice" (p. 4). By taking on the tension between justice as distribution versus recognition, the RPP is attempting to deepen the "college-for-all" policy discourse and build a foundation for change. Structures such as partnership retreats create time and space for these types of theoretical discussions. Co-presenting at conferences and finding other ways to engage in scholarship together are also key to advancing innovative ideas and practices.

Challenges: Learning to improve. As detailed above, the RPP designed a robust college-going culture and infrastructure that included a complex set of learning opportunities, relationships, and supports that extended across and outside of the school. Keeping track of this complex set was not only a coordination challenge for the college counselor, it was a research challenge to understand what and how the different resources contributed to students' college-going trajectories. Although student surveys and interviews provided insight into the need for additional support (e.g., for SAT prep or FAFSA support), the RPP struggled to identify key or high-leverage drivers that would ensure college-for-all; it also lacked the capacity needed to collect careful data on learning supports and program inputs. Overall, the tension was between adding more supports and programs and strategically pruning and improving the ones it had.

Current work on improvement science in education provides guidance for schools grappling with this tension. As Bryk, Gomez, Grunow, and LeMahieu (2015) outline, schools are quick to add programs without sufficient attention to learning what works in their context. Instead of "implementing fast and learning slow," the authors argue that schools should "learn fast to implement well." Improvement tools such as root causes analysis, driver diagrams, and process maps can help schools see and improve their college-going systems. Although a promising direction, this careful disciplined work of improvement at the school level must also attend to larger and often districtmandated reforms that layer programs on top of programs in an effort to support college-for-all. We turn now to a discussion of how our RPP informs this broader reform effort.

\section{Unpacking College-For-All}

As a case of public scholarship, the school's collective deliberation around the problems of framing, supporting, and tracking college-going has engaged the research literature, school data, and practical experience to articulate a college-going culture that provides insight and lessons for other schools. Overall, we have learned that "collegefor-all" is a concept that needs to be carefully unpacked and scrutinized. We present 
below three ways to deepen the public's understanding of this important policy movement.

Address participation parity and justice. Policy discourse about college-for-all rarely problematizes the tension between social justice as redistribution and recognition. As our case of public scholarship illustrates, this is a fundamental tension that can deepen policy and practice in this area. Fraser (1999) argues for a bivalent conception of justice that brings together justice claims for redistributing goods and recognizing the distinctive perspectives of particular groups (e.g., ethnic, racial, gender). She documents the way these two types of claims have been debated, with redistribution proponents rejecting the identity politics of recognition as a false consciousness that hinders the pursuit of social justice. Conversely, those who advocate for recognition see distributive politics tied to the failure of difference-blind egalitarianism. This is a false antithesis, Fraser argues, because injustice must be challenged on both fronts. She proposes the notion of parity of participation to guide action; in the case of collegefor-all, this norm would demand that students are not prevented from participating in college-either by a lack of resources and opportunities (distribution) or social esteem and respect (recognition).

Schools grapple with this tension because they are social institutions charged with furthering both economic and social aims. On one hand, the college-for-all movement is an economic reform to secure future employment. Postsecondary education has become a prerequisite for obtaining over $63 \%$ of our nation's jobs (Carnevale, Smith, \& Strohl, 2010). On the other, it is a social reform to recognize that everyone has the capability to pursue a life of their choosing (Nussbaum, 2002). As Appiah (2001) deftly puts it, education "frees people to develop lives worth living." (p. 330) The college-forall movement is therefore poised to advance both economic justice while also contributing to this notion of freedom, contextualized by identity, history, and culture.

In considering McClafferty, et al.'s (2002) college-going model, schools have to deliberate about how to incorporate the nine principles in ways that maintain their vision of social justice. As our RPP found, this involves attending to the college status hierarchies, and grappling with the differential esteem and respect experienced by students attending two- versus four-year institutions as well as selective versus nonselective colleges. Distributive arguments in favor of college-for-all must also address the question, access to what? While college-for-all has created more opportunities for students of color and low-income students to attend college, less selective two- and four-year institutions account for much of this expansion (Arum, Gamoran, \& Shavit, 2007). Students attending selective K-12 institutions are using their privilege and access to diverse resources to distinguish themselves from the masses by seeking out the most competitive postsecondary institutions (Weis, Cipollone, \& Jenkins, 2013). At the same time, as the college choice literature demonstrates, underrepresented students often enroll in "undermatched" lower status institutions because of a lack of navigational support (Roederick, Koka, \& Nagaoka, 2011), cementing the stratification of college access along lines of race and class. Therefore, while more students are attending college, the value of these opportunities for many students has diminished (Arum et al., 2007), thus complicating the work of college counseling in high schools. This research highlights the importance of tracking college-going and enrollment to understand the extent to which the college-for-all movement is perpetuating systemic inequalities rather than diminishing them. 
Create supports to meet higher standards. The case of Juan illustrated how students who fall off the college track early in high school can regain their footing by taking online classes in senior year. It also demonstrates how creative solutions, such as gap years, can open alternative pathways to students. Researchers are just starting to document the implications of widespread credit recovery and heightened graduation requirements in a college-for-all context. A recent study of how A-G for all reform affects students' college access and high school graduation rates in the San Diego Unified School District (SDUSD) found that while 10\% more students in the class of 2016 may become eligible to apply to a public university, 16\% more of these students may fail to graduate (Betts, Zau, \& Bachofer, 2016). These findings hold many implications for districts that have adopted college-for-all policies. For one, they require a critical examination of how college-for-all reform is executed in schools. Simply making college preparatory coursework available to students is not enough to ensure their successful completion of these courses and subsequent eligibility for graduation and/or for public universities. Students need substantial and differentiated levels of support to meet these requirements and teachers and school leaders need support to raise expectations, scaffold a more rigorous curriculum, and effectively provide the supports students need.

As districts lack the resources and capacity to provide timely support, major urban districts across California have increased their investment in credit recovery programs and summer school coursework (Betts et al., 2016; Clough \& Favot, 2016). While these investments may help to increase the graduation rate of students, they do much less for students' eligibility for public universities and preparation for college overall. As a result, more students face the burden of remedial coursework upon entering college, which has been found to decrease postsecondary persistence and completion rates (Bailey, Jeong, \& Cho, 2010).

Embracing the complexity of the college-for-all movement requires addressing a variety of support structures and dimensions of the college-going and enrollment process (Perna, 2006). We must consider that federal and state financial aid fails to cover a large portion of costs associated with college attendance for many low-income, firstgeneration students (Goldrick-Rab, 2016). This poses a challenge in ensuring that students will have the funds necessary to enroll in college without having to assume loans or work long hours. In addition, certain student populations, such as those who are undocumented, encounter additional barriers in the college-for-all process. They are ineligible to receive federal financial aid and in most states do not qualify in-state tuition or any type of financial aid support (Gonzales, 2011; Murillo, 2017). The everchanging political landscape has created additional confusion and barriers for undocumented students. For instance, the Deferred Action for Childhood Arrivals (DACA) program, which provides undocumented youth reprieve from deportation, a Social Security number, and a work permit (Gonzales, Terriquez \& Ruszczyk, 2014) was rescinded by the Trump administration in September 2017. At present, individuals with DACA, at the time it was rescinded, are able to submit a renewal application, but no new applications are being accepted. As a result, the fear of deportation and curtailed opportunities (e.g., ability to work legally) may deter some students from applying to college (Romero, 2017).

As the goal of college-for-all reform is to provide a college preparatory curriculum and increase access to public universities for all students, there is a need for research that (a) demonstrates models of success, (b) grapples with complex college-for-all implementation issues, and (c) offers insights for building the capacity to support students to 
meet these requirements. In the particular instance of this school site, both the graduation rate and college-going rate have increased. While the site presents a model of success, it nevertheless remains a space where questions surrounding rigor of curriculum, credit recovery, grading, and A-G For All implementation persist and continue to be topics for dialogue. The RPP continues to engage in ongoing efforts to track alumni and to understand their experiences both in college and the workforce in an attempt to understand the repercussions of the K-12 educational experience being offered to students.

Owning what it really takes. Education reform is notorious for unfunded mandates-policies handed down to schools with inadequate support, resources, and follow-through. In describing how a new school designed a college-going culture that resulted in higher than average college enrollment and persistence for first-generation students, we have aimed to make transparent the conceptual and material work involved in implementing a district-mandated college-for-all reform. Yet, we are also very aware that deep systemic inequalities continue to define the reform landscape. The fact that our work was accomplished in the context of a research-practice partnership calls into question its generalizability to other school contexts, but it also provides insight into the supports schools need to make college-for-all a reality. As noted above, we are not claiming to know the efficacy of particular strategies or components of the school's college-going culture; what we do know is that a multi-year process of collective problem-solving resulted in a set of practices, structures, roles, beliefs, and norms that supported college for (almost) all students. Aside from the particularities of the supports designed, the RPP effort sought to capture the many dimensions of the college-for-all problem-solving space. From theoretical problems surrounding justice to budgetary and program coordination issues, to data collection and management problems, our RPP had to grapple with multiple and overlapping issues. From a human capacity standpoint, we also shared an intensity of experience familiar to many educators and schools advancing college for first-generation students. This work is hard, it demands strong and trusting relationships with students and families, and it goes far beyond completing a set of required courses. For this promising equity-focused reform to take hold, the public must own what it really takes.

\section{References}

Adelman, C. (2006). The toolbox revisited: Paths to degree completion from high school through college. Washington DC: US Department of Education.

Anderson, T., \& Shattuck, J. (2012). Design-based research: A decade of progress in education research?. Educational researcher, 41(1), 16-25.

Appiah, K. A. (2001). Liberalism, individuality, and identity. Critical Inquiry, 27(2), 305-332.

Arum, R., Gamoran, A., \& Shavit, Y. (2007). More inclusion than diversion: Expansion, differentiation, and market structure in higher education. Stratification in higher education: A comparative study, 1-35.

Bailey, T., Jeong, D. W., \& Cho, S. W. (2010). Referral, enrollment, and completion in developmental education sequences in community colleges. Economics of Education Review, 29(2), 255-270.

Balfanz, R., \& Letgers, N. (2004). Locating the dropout crisis: Which high schools produce the nation's dropouts? Where are they located? Who attends them? Report 70. Baltimore, MD: Center for Research on the Education of Students Placed At Risk. Retrieved July 14, 2009.

Belasco, A. S. (2013). Creating college opportunity: School counselors and their influence on postsecondary enrollment. Research in Higher Education, 54(7), 781-804.

Benson, L., Harkavy, I. R., Puckett, J. L., Hartley, M., Hodges, R. A., Johnston, F. E., \& Weeks, J. (2017). Knowledge for social change: Bacon, Dewey, and the revolutionary transformation of research universities in the twenty-first century. Temple University Press.

Bernal, D. (2002). Critical race theory, Latino critical theory, and critical raced-gendered epistemologies: Recognizing students of color as holders and creators of knowledge. Qualitative inquiry, 8(1), 105-126.

Betts, J. R., Zau, A. C., \& Bachofer, K. V. (2013). College readiness as a graduation requirement: An assessment of San Diego's challenges. San Francisco, CA: Public Policy Institute of California. 
Borudieu, P. (1986). The forms of capital. In J.G. Richardson (ed.), Handbook of Theory and Research for the Sociology of Education (pp. 241-258). New York: Greenwood Press.

Bryk, A. S., Gomez, L. M., Grunow, A., \& LeMahieu, P. G. (2015). Learning to Improve: How America's Schools Can Get Better at Getting Better. Cambridge, MA: Harvard Education Press.

Carnevale, A. P., Smith, N., \& Strohl, J. (2010). Help wanted: Projections of job and education requirements through 2018. Lumina Foundation.

Ceja, M. (2006). Understanding the role of parents and siblings as information sources in the college choice process of Chicana students. Journal of College Student Development, 47(1), 87-104.

Clough, C. \& Favot, S. (2016) LAUSD boots up credit recovery courses at start of new school year. LA School Report. Retrieved from http://laschoolreport.com/lausd-boots-up-credit-recovery-courses-at-start-of-newschool-year/

Coburn, C. E. (2016) "What's policy got to do with it? How the structure-agency debate can illuminate policy implementation," American Journal of Education, 122(3), 465-475.

Coburn, C. E., Bae, S., \& Turner, E. O. (2008). Authority, status, and the dynamics of insider-outsider partnerships at the district level. Peabody Journal of Education, 83(3), 364-399.

Coburn, C. E., \& Penuel, W. R. (2016). Research-Practice Partnerships in Education: Outcomes, Dynamics, and Open Questions. Educational Researcher, 45(1), 48-54.

Coburn, C. E., Penuel, W. R., \& Geil, K. E. (2013). Research-Practice Partnerships: A Strategy for Leveraging Research for Educational Improvement in School Districts. William T. Grant Foundation.

Conley, D. T. (2012). A complete definition of college and career readiness. Educational Policy Improvement Center. Retrieved from http://www.epiconline.org/publications/documents/College+and+Career+ Readiness+Definition.pdf

Cucchiara, M. (2010). New Goals, Familiar Challenges?: A Brief History of University-Run Schools. Penn GSE Perspectives on Urban Education, 7(1), 96-108.

Darling-Hammond, L. (2000). Teacher quality and student achievement. Education policy analysis archives, $8,1$.

De La Rosa, D., Luna, M., \& Tierney, W. G. (2006). Breaking through the Barriers to College: Empowering LowIncome Communities, Schools, and Families for College Opportunity and Student Financial Aid. Center for Higher Education Policy Analysis, University of Southern California.

Domina, T., Conley, A., \& Farkas, G. (2011). The link between educational expectations and effort in the college-for-all era. Sociology of Education, 84(2), 93-112.

Engberg, M. E., \& Wolniak, G. C. (2010). Examining the effects of high school contexts on postsecondary enrollment. Research in Higher Education, 51(2), 132-153.

Farmer-Hinton, R. L. (2008). Social capital and college planning students of color using school

networks for support and guidance. Education and Urban Society, 41(1), 127-157.

Farmer-Hinton, R. (2011). On being college prep: Examining the implementation of a "college for all"

mission in an urban charter school. The Urban Review, 43(5), 567-596.

Fraser, N. (1999). Social justice in the age of identity politics: Redistribution, recognition, and participation. In Ray, L. and Sayer, A. (Eds.) Culture and economy after the cultural turn, 25-52.

Gandara, P. C., \& Contreras, F. (2009). The Latino education crisis: The consequences of failed social policies. Harvard University Press.

Gibson, M. A., Gandara, P. C., \& Koyama, J. P. (Eds.). (2004). School connections: US Mexican youth, peers, and school achievement. Teachers College Press.

Goldrick-Rab, S. (2016). Paying the price: College costs, financial aid, and the betrayal of the American dream. Chicago, IL: University of Chicago Press.

Gonzales, R. G. (2011). Learning to be illegal: Undocumented youth and shifting legal contexts in the transition to adulthood. American Sociological Review, 76(4). doi: 10.1177/0003122411411901

González, K. P., Stoner, C., \& Jovel, J. E. (2003). Examining the role of social capital in access to college for Latinas: Toward a college opportunity framework. Journal of Hispanic Higher Education, 2(2), 146-170.

Gonzales, R. G., Terriquez, V., \& Ruszczyk, S. P. (2014). Becoming DACAmented: Assessing the short-term benefits of deferred action for childhood arrivals (DACA). American Behavioral Scientist, 58(14), 1852-1872. doi: 10.1177/0002764214550288

Hill, D. H. (2008). School strategies and the "college-linking” process: Reconsidering the effects of high schools on college enrollment. Sociology of education, 81(1), 53-76.

Holcomb-McCoy, C. (2010). Involving low-income parents and parents of color in college readiness activities: An exploratory study. Professional School Counseling, 14(1), 115-124.

Holland, N. E., \& Farmer-Hinton, R. L. (2009). Leave no schools behind: The importance of a college culture in urban public high schools. The High School Journal, 92(3), 24-43.

Hossler, D., \& Gallagher, K. S. (1987). Studying student college choice: A three-phase model

and the implications for policymakers. College and university, 62(3), 207-21.

Howard, T. C., \& Milner, H. R. (2014). Teacher preparation for urban schools. Handbook of urban education, 199-216. 
Irizarry, J. G. (2009). Representin’Drawing From Hip-Hop and Urban Youth Culture to Inform Teacher Education. Education and Urban Society, 41(4), 489-515.

Jacobo, S. \& Quartz, K.H. (2019). UCLA Community School longitudinal college-going data report. UCLA Center for Community Schooling.

Kanno, Y., \& Cromley, J. G. (2015). English language learners' pathways to four-year colleges. Teachers College Record, 117(120306), 1-46.

Kelly, A. E. (2004). Design research in education: Yes, but is it methodological? Journal of the Learning Sciences, 13(1), 113-128.

Kim, D. H., \& Schneider, B. L. (2005). Social capital in action: Alignment of parental support in adolescents' transition to postsecondary education. Social forces, 84(2), 1181-1206.

Knight-Diop, M. G. (2010). Closing the gap: Enacting care and facilitating black students' educational access in the creation of a high school college-going culture. Journal of Education for Students Placed at Risk, 15(1-2), 158-172.

Ladson-Billings, G. (2006). From the achievement gap to the education debt: Understanding achievement in US schools. Educational researcher, 35(7), 3-12.

Lipman, P. (2013). Economic crisis, accountability, and the state's coercive assault on public education in the USA. Journal of Education Policy, 28(5), 557-573.

Liou, D. D., Antrop-Gonzalez, R., \& Cooper, R. (2009). Unveiling the promise of community cultural wealth to sustaining Latina/o students' college-going information networks. Educational Studies, 45(6), 534-555.

Martinez, G.F., \& Deil-Amen, R. (2015). College for all Latinos? The role of high school messages in facing college challenges. Teachers College Record, 117(3), 1-50.

Martinez, M. A., \& Welton, A. (2014). Examining college opportunity structures for students of color at high"minority," high-poverty secondary schools in Texas. Journal of School Leadership, 24(5), 800-841.

McClafferty, K. A., McDonough, P. M., \& Nunez, A. M. (2002). What Is a College Culture? Facilitating College Preparation through Organizational Change.

McDonough, P. M. (1997). Choosing colleges: How social class and schools structure opportunity. SUNY Press.

McKillip, M. E., Godfrey, K. E., \& Rawls, A. (2013). Rules of engagement: Building a college-going culture in an urban school. Urban Education, 48(4), 529-556.

Mehan, H. (2012). In the front door: Creating a college-going culture of learning. Routledge.

Murillo, M. A. (2017). Undocumented and college-bound: A case study of the supports and

barriers high school students encounter in accessing higher education. Urban Education.

Advance online publication. doi: 10.1177/0042085917702200.

National Research Council. (2012). A framework for K-12 science education: Practices, crosscutting concepts, and core ideas. National Academies Press.

Noguera, P. A. (2003). The trouble with Black boys: The role and influence of environmental and cultural factors on the academic performance of African American males. Urban education, 38(4), 431-459.

Noguera, P. A. (2009). The trouble with black boys:... And other reflections on race, equity, and the future of public education. John Wiley \& Sons.

Nussbaum, M. (2002). Education for citizenship in an era of global connection. Studies in Philosophy and Education, 21(4), 289-303.

Ochoa, G. L. (2013). Academic Profiling: Latino, Asian Americans, and the achievement gap.

Minneapolis, MN: University of Minnesota Press.

Oropeza, M. V., Varghese, M. M., \& Kanno, Y. (2010). Linguistic minority students in higher education: Using, resisting, and negotiating multiple labels. Equity \& Excellence in Education, 43(2), 216-231.

Penuel, W. R. (2015). Infrastructuring As a Practice for Promoting Transformation and Equity in DesignBased Implementation Research. Keynote presented at the International Society for Design and Development in Education (ISDDE) 2015 Conference, Boulder, CO, September 22, 2015.

Penuel, W. R., Allen, A. R., Coburn, C. E., \& Farrell, C. (2015). Conceptualizing research-practice partnerships as joint work at boundaries. Journal of Education for Students Placed at Risk (JESPAR), 20(1-2), 182-197.

Perez, P. A., \& McDonough, P. M. (2008). Understanding Latina and Latino college choice: A social capital and chain migration analysis. Journal of Hispanic higher education.

Perez-Felkner, L. (2015). Perceptions and resilience in underrepresented students' pathways to college. Teachers College Record, 117(8), 1. Perna, L. W. (2006). Studying college access and choice: A proposed conceptual model. In Higher Education: Handbook of theory and research (Vol 21, pp. 99-157). Netherlands: Springer

Person, A. E., \& Rosenbaum, J. E. (2006). Chain enrollment and college enclaves: Benefits and drawbacks of Latino college students' enrollment decisions. New directions for community colleges, 2006(133), 51-60.

Phillips, M., Yamashiro, K., Farrukh, A., Lim, C., Hayes, K., Wagner, N., ... \& Chen, H. (2015). Using research to improve college readiness: A research partnership between the Los Angeles Unified School District and the Los Angeles Education Research Institute. Journal of Education for Students Placed at Risk (JESPAR), 20(1-2), 141-168. 
Pike, G. R., \& Kuh, G. D. (2005). First-and second-generation college students: A comparison of their engagement and intellectual development. The Journal of Higher Education, 76(3), 276-300.

Quartz, K. H., Weinstein, R. S., Kaufman, G., Levine, H., Mehan, H., Pollock, M., Priselac, J. Z. \& Worrell, F. C. (2017). University-partnered new school designs: Fertile ground for research-practice partnerships. Educational Researcher, 46(3), 143-146.

Rios-Aguilar, C., Kiyama, J. M., Gravitt, M., \& Moll, L. C. (2011). Funds of knowledge for the poor and forms of capital for the rich? A capital approach to examining funds of knowledge. Theory and Research in Education, 9(2), 163-184.

Roderick, M., Coca, V., \& Nagaoka, J. (2011). Potholes on the road to college: High school effects in shaping urban students' participation in college application, four-year college enrollment, and college match. Sociology of Education, 84(3), 178-211.

Roderick, M., Nagaoka, J., \& Coca, V. (2009). College readiness for all: The challenge for urban high schools. The Future of Children, 19(1), 185-210.

Romero, E. F. (2017). Far fewer undocumented students are applying for financial aid to attend California colleges-advocates cite fear and the end of DACA. LA School Report, November 15, 2017. Retrieved 12/4/17 http://laschoolreport.com/far-fewer-undocumented-students-are-applying-for-financialaid-to-attend-california-colleges-advocates-cite-fear-and-the-end-of-daca/

Rosenbaum, J. (2001). Beyond college-for-all: Career paths for the forgotten half. New York: Russell Sage Foundation

Sirotnik, K. A., \& Goodlad, J. I. (Eds.). (1998). School-university partnerships in action: Concepts, cases and concerns. New York, NY: Teachers College Press.

Stanton-Salazar, R. D. (2001). Manufacturing hope and despair: The school and kin support networks of USMexican youth. Teachers College Press.

Teranishi, R. T. (2002). Asian Pacific Americans and critical race theory: An examination of school racial climate. Equity \&Excellence in Education, 35(2), 144-154.

Tornatzky, L. G., Cutler, R., \& Lee, J. (2002). College knowledge: What Latino parents need to know and why they don't know it. Claremont, CA: Tomas Rivera Policy Institute.

University of California (2017). A-G Guide. A-G Subject Requirements. Retrieved from https://www.ucop. edu/agguide/a-g-requirements/

Valenzuela, A. (1999). Subtractive schooling: Issues of caring in education of US-Mexican youth. State University of New York Press.

Weis, L., Cipollone, K., \& Jenkins, H. (2014). Class warfare: Class, race and college admissions in top-tier secondary schools. Chicago, IL: University of Chicago Press.

Welton, A. D., \& Martinez, M. A. (2014). Coloring the college pathway: A more culturally responsive approach to college readiness and access for students of color in secondary schools. The Urban Review, 46(2), 197-223.

Yosso, T. J. (2005). Whose culture has capital? A critical race theory discussion of community cultural wealth. Race ethnicity and education, 8(1), 69-91.

Zirkel, S. (2004). What will you think of me? Racial integration, peer relationships and achievement among White students and students of color. Journal of Social Issues, 60(1), 57-74.

\section{疅}


Copyright of High School Journal is the property of University of North Carolina Press and its content may not be copied or emailed to multiple sites or posted to a listserv without the copyright holder's express written permission. However, users may print, download, or email articles for individual use. 